\title{
PEMANFAATAN EKSTRAK BUNGA KECOMBRANG (Etlingera elatior jack R.M.sm) SEBAGAI LARVASIDA NYAMUK (Culex quinquifasciatus Say)
}

\author{
Bagus Uda Palgunadi ${ }^{1}$, Lailia Dwi Kusuma Wardhani ${ }^{1}$, Ni Made Dewi Lestari ${ }^{1}$, Indra Rahmawati ${ }^{{ }^{*}}$ \\ ${ }^{1}$ Fakultas Kedokteran Hewan, Universitas Wijaya Kusuma Surabaya \\ *Email : indra_rachma07@yahoo.com
}

\begin{abstract}
This study aims to determine the effectiveness of kecombrang flower extract (Etlingera elatior jack R.M.sm) on the death of Culex quenquefasciatus Say larvae. Experimental animals used were Culex quenquefasciatus Say larvae, amounting to 625 tails. The design used was a randomized complete design with 5 treatments and 5 replications. The five treatments consisted of two test groups, namely the treatment group consisting of concentrations of 5\%, 10\%, 15\%, and the control group consisting of positive control namely abate and negative control namely aquades. Observation of mosquito larvae death was done every 2 hours for 12 hours. The data obtained were analyzed using the one-way ANOVA test and continued with the Duncan test. Based on the results of the one way ANOVA calculation the value of sig. $0.00<0.05$ means that there are significant differences between treatments. Duncan test results on the treatment of $10 \%$ and $15 \%$ kecombrang flower extract have the ability as a larvicide high and equal to positive control (abate). Based on the results of the study it was concluded that the extract of kecombrang flower (Etlingera elatior jack R.M.sm) had the ability to larvae against the Culex quenquefasciatus Say mosquito.
\end{abstract}

Keyword : Culex quenquefasciatus Say, kecombrang flower extract, larvacide

\section{PENDAHULUAN}

Negara Indonesia merupakan salah satu negara tropis terbesar di dunia yang memiliki dua musim, yaitu musim hujan dan musim kemarau yang mendukung bagi kelangsungan hidup serangga. Penyakit tropis oleh salah satu serangga seperti nyamuk dapat menyebabkan malaria, demam berdarah, filariasis (kaki gajah), dan chikungunya yang dapat menjangkit pada masyarakat, dan menimbulkan wabah. Penyebab utama yang dapat menimbulkan wabah dari berbagai penyakit tropis tersebut adalah perkembangbiakan dan penyebaran nyamuk yang tidak dapat dikendalikan (Khumaisah dkk.,2010).

Nyamuk merupakan salah satu jenis serangga yang dapat berperan sebagai vektor penyakit. Menurut Putri dkk., (2017) Nyamuk Culex merupakan nyamuk rumah yang habitatnya di tempat yang kotor dan mempunyai kebiasaan menyimpan telur di air yang kotor. Nyamuk Culex melalui empat tahap yang berbeda dalam siklus hidupnya, yaitu telur, larva, pupa, dan dewasa. Nyamuk yang termasuk dalam genus Culex dikenal sebagai vektor penular arbovirus, demam kaki gajah dan malaria yang menyerang pada unggas.

Nyamuk genus ini merupakan nyamuk yang banyak terdapat disekitar lingkungan. Selain itu, nyamuk ini juga termasuk serangga yang beberapa spesiesnya sudah dapat dibuktikan sebagai vektor penyakit, disamping dapat mengganggu kehidupan manusia melalui gigitannya (Ahdiyah dkk., 2015).

Salah satu cara memutus mata rantai penyebaran nyamuk tersebut adalah dengan cara pengendalian vektor dengan menggunakan insektisida. Pengendalian serangga pada umumnya menggunakan insektisida sintetik (Ahdiyah dkk., 2015). Menurut Khumaisah dkk., (2010) Saat ini telah banyak insektisida yang digunakan oleh masyarakat yang dianggap efektif dan praktis, seperti abate akan tetapi penggunaan insektisida yang dilakukan secara terusmenerus juga dapat membawa dampak negatif terhadap manusia atau lingkungan 
karena mengandung senyawa-senyawa kimia yang berbahaya.

Pengembangan insektisida baru yang tidak menimbulkan bahaya dan lebih ramah dengan lingkungan diharapkan dapat diperoleh melalui penggunaan bioinsektisida. Bioinsektisida atau larvasida adalah suatu insektisida yang bahan dasarnya berasal dari tumbuhan yang mengandung bahan kimia aktif yang bersifat racun terhadap serangga tetapi mudah terurai (biodegradable) di alam sehingga tidak mencemari lingkungan dan relatif aman bagi manusia (Khumaisah dkk., 2010).

Banyak tanaman yang memiliki kemampuan sebagai bioinsektisida yang dapat digunakan sebagai pemutus siklus larva nyamuk Culex, salah satunya adalah tanaman bunga kecombrang. Bunga kecombrang (Etlingera elatior Jack R. M. $S m$ ) merupakan salah satu tanaman yang memiliki potensi insektisida, karena mengandung zat aktif alkaloid, flavonoid, polifenol, steroid, saponin dan minyak atsiri (Fuadzy dan Marina, 2012).

Kandungan senyawa zat aktif inilah yang menjadi dasar dilakukannya penelitian mengenai efektivitas ekstrak bunga kecombrang (Etlingera elatior Jack R. M. $\mathrm{Sm}$ ) sebagai bioinsektiseda terutama larvasida dari nyamuk Culex quinquefasciatus Say. Diharapkan ekstrak ini dapat menjadi alternatif baru untuk mengurangi resiko dari insektisida yang menggunakan zat kimia.

Karena belum terdapat penelitian mengenai ekstrak bunga kecombrang (Etlingera elatior Jack R.M sm) terhadap larva nyamuk Culex quinquefasciatus Say, peneliti ingin meneliti efektivitas ekstrak bunga kecombrang (Etlingera elatior Jack R.M sm) terhadap kematian larva nyamuk Culex quinquefasciatus Say.

\section{MATERI DAN METODE}

Penelitian ini dilakukan di Laboratorium Penelitian dan Konsultasi Industri. Penelitian ini dilaksanakan pada 16 maret sampai dengan 6 april tahun 2020.

Penelitian ini merupakan penelitian yang bersifat eksperimental laboratorium yang bertujuan untuk mengetahui efektivitas ekstrak bunga kecombrang (Etlingera elatior Jack R.M sm) terhadap kematian larva nyamuk Culex quinquefasciatus Say. Ekstrak bunga kecombrang adalah ekstrak yang dihasilkan dari bunga kecombrang yang dikeringkan dengan teknik ekstraksi maserasi dengan penggunan pelarut etanol $75 \%$.

Proses pembuatan ekstrak dimulai dari pengeringan sampai terbentuk ekstrak yang dikerjakan oleh tenaga ahli di Balai Penelitian dan Konsultasi Industri Surabaya. Sampel penelitian yang digunakan sejumlah 625 ekor larva nyamuk Culex quinqeufasciatus Say yang diperoleh dari Laboratorium Entomologi Tropical Disease Diagnostic Center (TDDC) Kampus C UNAIR, Mulyorejo, Surabaya. Tiap perlakuan membutuhkan 25 ekor larva nyamuk Culex quiquefasciatus Say.

Pada penelitian ini dibutuhkan lima perlakuan dan lima ulangan. Kelima perlakuan tersebut terdiri dari dua kelompok uji, yaitu kelompok perlakuan yang terdiri dari konsentrasi 5\%, 10\%, 15\% dan kelompok kontrol yang terdiri dari kontrol positif yaitu abate dan kontrol negatif yaitu aquades. Larutan untuk perlakuan dibuat dengan melarutkan ekstrak bunga kecombrang $5 \mathrm{ml}, 10 \mathrm{ml}$ dan $15 \mathrm{ml}$ dalam $250 \mathrm{ml}$ air. Setiap perlakuan berisi 25 ekor larva nyamuk Culex quinquefasciatus Say yang ditaruh pada masing-masing tabung plastik.

Untuk mengetahui bahwa larva nyamuk telah mati yaitu larva yang mati merupakan larva yang tidak bergerak dan tidak memberikan respon terhadap berbagai rangsangan, yakni gerakan di dalam air dengan sentuhan lidi atau jarum. Larva nyamuk yang mati kemudian di rendam dengan alkohol. Jika ada larva yang tidak mati juga direndam dengan alkohol.

Pegamatan dilakukan setiap 2 jam selama 12 jam. Jumlah larva nyamuk yang mati dihitung dan dimasukan ke dalam tabel dan dianalisis dengan uji one way ANOVA dan dilanjutkan dengan uji Duncan 5\%. 
HASIL

Adapun hasil penelitian ini, tercantum dalam beberapa tabel di bawah ini :

Tabel 1. Jumlah Kematian Larva Nyamuk Perlakuan Jumlah Kematian Nyamuk Culex quenquefasciatus Say

\begin{tabular}{cc} 
& $(\%)$ \\
\hline $\begin{array}{c}\text { Aquades (Kontrol } \\
\text { negatif) }\end{array}$ & 0 \\
\hline Abate (Kontrol Positif) & 100 \\
\hline $\begin{array}{c}\text { Ekstrak bunga } \\
\text { kecombrang (Etlingera } \\
\text { elatior Jack R.M sm) } \\
5 \%\end{array}$ & 52 \\
\hline $\begin{array}{l}\text { Ekstrak bunga } \\
\text { kecombrang (Etlingera } \\
\text { elatior Jack R.M sm) } \\
10 \%\end{array}$ \\
$\begin{array}{l}\text { Ekstrak bunga } \\
\text { kecombrang (Etlingera } \\
\text { elatior Jack R.M sm) } \\
15 \%\end{array}$ \\
\hline
\end{tabular}

Nyamuk Culex quenquefasciatus Say sebanyak 625 ekor dibagi ke dalam 5 perlakuan dan 5 ulangan terdiri dari 25 ekor larva nyamuk pada setiap ulangan dengan rancangan penelitian menggunakan Rancangan Acak Lengkap (RAL) yang masing-masing perlakuannya terdiri dari kontrol positif (abate), kontrol negatif (aquades), konsentrasi ekstrak bunga kecombrang 5\%, 10\%, dan $15 \%$. Tiap perlakuan dilakukan pengamatan setiap 2 jam selama 12 jam.

Tabel 2. Perbedaan Waktu Tingkat Kematian diantara Perlakuan

\begin{tabular}{lc}
\hline \multicolumn{1}{c}{ Perlakuan } & Mean \pm Std. deviation \\
\hline Aquades (Kontrol negatif) & $0,00 \pm 0,000^{\mathrm{a}}$ \\
\hline Abate (Kontrol Positif) & $25,0 \pm 0,000^{\mathrm{c}}$ \\
\hline Ekstrak bunga kecombrang & $13,0 \pm 1,581^{\mathrm{b}}$ \\
(Etlingera elatior Jack & \\
R.M sm) 5\% & \\
\hline Ekstrak bunga kecombrang & $24,6 \pm 0,548^{\mathrm{c}}$ \\
(Etlingera elatior Jack & \\
R.M sm) 10\% & \\
\hline Ekstrak bunga kecombrang & $24,8 \pm 0,447^{\mathrm{c}}$ \\
(Etlingera elatior Jack & \\
R.M sm) 15\% & \\
\hline
\end{tabular}

Berdasarkan pengujian yang dilakukan nilai Sig. 0,000 ( $<<0,005)$, maka terdapat perbedaan yang signifikan antar perlakuan. Sehingga HO ditolak dan H1 diterima, sehingga terdapat perbedaan yang nyata antar perlakuan- Untuk mengetahui perbedaan antar perlakuan maka dilanjutkan uji lanjutan menggunakan uji Duncan.

Tabel 3. Hasil Statistika Uji Duncan Perbedaan Waktu Tingkat Kematian diantara Perlakuan

\begin{tabular}{|c|c|c|c|c|}
\hline Perlakuan & $\mathrm{N}$ & A & B & $\mathrm{C}$ \\
\hline $\begin{array}{l}\text { Aquades } \\
\text { (Kontrol } \\
\text { negatif) }\end{array}$ & 5 & .00 & & \\
\hline $\begin{array}{l}\text { Ekstrak bunga } \\
\text { kecombrang } \\
\text { (Etlingera } \\
\text { elatior Jack } \\
\text { R.M sm) 5\% }\end{array}$ & 5 & & 13.00 & \\
\hline $\begin{array}{l}\text { Ekstrak bunga } \\
\text { kecombrang } \\
\text { (Etlingera } \\
\text { elatior Jack } \\
\text { R.M sm) } 10 \%\end{array}$ & 5 & & & 24.60 \\
\hline $\begin{array}{l}\text { Ekstrak bunga } \\
\text { kecombrang } \\
\text { (Etlingera } \\
\text { elatior Jack } \\
\text { R.M sm) } 15 \%\end{array}$ & 5 & & & 24.80 \\
\hline $\begin{array}{l}\text { Abate (Kontrol } \\
\text { Positif) }\end{array}$ & 5 & & & 25.00 \\
\hline sig & & 1.000 & 1.000 & 450 \\
\hline
\end{tabular}

Hasil uji lanjutan menggunakan uji Duncan menunjukan notasi yang berbeda. Kontrol negatif aquades berbeda nyata dengan ekstrak $5 \%$ dan berbeda nyata dengan kontrol positif, ekstrak $10 \%$ dan ekstrak $15 \%$. Sedangkan ekstrak $10 \%$ dan ekstrak $15 \%$ tidak memiliki perbedaan yang nyata dengan kontrol positif abate. 
Tabel 4. Hasil Skrining Fitokimia Ekstrak Bunga Kecombrang (Etlingera elatior)

\begin{tabular}{cc}
\hline Tes Uji & Hasil \\
\hline Flavonoid & $2,11 \%$ \\
\hline Terpenoid & $3,08 \%$ \\
\hline Saponin & $1,92 \%$ \\
\hline Tanin & $0,31 \%$ \\
\hline Alkaloid & $4,62 \%$ \\
\hline Minyak atsiri & $1,67 \%$ \\
\hline
\end{tabular}

Hasil dari uji skrining fitokimia ekstrak bunga kecombrang (Etlingera elatior) menunjukkan hasil senyawa alkaloid yang paling tinggi yaitu $4,62 \%$ kemudian terpenoid $3,08 \%$, flavonoid $2,11 \%$, saponin $1,92 \%$, minyak atsiri $1,67 \%$ dan tanin $0,31 \%$.

\section{PEMBAHASAN}

Mekanisme dari kerja larvasida dalam membunuh larva yaitu dengan masuk melalui kontak kulit. Dapat diaplikasikan langsung menembus bagian integument serangga (kutikula) trakea atau kelenjar sensorik dan organ lain yang berhubungan dengan kutikula (Pradani dkk., 2011). Larvasida ini juga dapat masuk kedalam tubuh melalui mulut dikarenakan racun yang masuk melalui makanan.

Kemudian dapat menghambat transport elektron dalam mitokondria sehingga pembentukan energi dalam sel tidak terbentuk sehingga sel tidak dapat beraktifitas dan dapat menyebabkan larva mati (Ahdiyah dan Purwani., 2015). Bahan kimia yang terkandung dalam insektisida melarutkan lemak dan lapisan lilin pada kutikula sehingga menyebabkan bahan aktif yang terkandung dalam insektisida tersebut dapat menembus tubuh serangga (Pradani, dkk. 2011).

Hasil pengujian efektifitas esktrak bunga kecombrang sebagai larvasida terhadap larva nyamuk Culex quinquefasciatus Say selama pengujian berlangsung, suhu pada ruang uji berkisar antara $27,6^{\circ} \mathrm{C}-28,8^{\circ} \mathrm{C}$. Menurut Wijayanti, dkk. (2015), bahwa dalam penelitiannya tentang pengaruh suhu dan tingkat kelangsungan hidup nyamuk Culex quinquefasciatus tumbuh dengan baik pada kisaran suhu ruangan $20{ }^{\circ} \mathrm{C}-30{ }^{\circ} \mathrm{C}$. Berdasarkan hal tersebut, suhu dalam ruang uji yang digunakan pada penelitian ini masih berada pada kisaran standard yaitu $27,6^{\circ} \mathrm{C}-$ $28,8^{\circ} \mathrm{C}$.

Pengukuran terhadap $\mathrm{pH}$ air mineral dan $\mathrm{pH}$ setelah dicampurkan ekstrak bunga kecombrang yang digunakan dalam penelitian ini adalah menggunakan $\mathrm{pH}$ meter, hasil pengukurannnya yaitu $\mathrm{pH} 6-7$. Berdasarkan Low et al, (2012) menyatakan bahwa untuk kehidupan larva nyamuk Culex quinquefasciatus Say $\mathrm{pH}$ air berkisar antara 5,8-8,5. Berdasarkan hal tersebut, $\mathrm{pH}$ air yang digunakan dalam penelitian ini masih berada pada kisaran standart yaitu pH 6-7.

Data kematian larva Culex quinquefasciatus yang diperoleh dianalisis secara statistik dengan menggunakan uji one way ANOVA untuk mengetahui apakah penggunaan ekstrak bunga kecombrang berpengaruh secara signifikan terhadap kematian larva Culex quinquefasciatus. Berdasarkan hasil perhitungan one way ANOVA di atas (4.2), nilai Sig yang diperoleh yaitu 0,00 dan $\alpha$ 0,05 maka H0 ditolak yang artinya perlakuan yang diberikan berpengaruh nyata pada taraf 5\% (p $0,00<0,05)$ dan $\mathrm{H} 1$ diterima yang artinya terdapat perbedaan pengaruh ekstrak bunga kecombrang dari berbagai konsentrasi sebagai larvasida terhadap larva nyamuk Culex quinquefasciatus.

Untuk melihat perbedaan tingkat efektifitas perlakuan dilakukan uji lanjutan Duncan antar perlakuan. Berdasarkan hasil uji Duncan (tabel 4.3) dengan $\alpha \quad 0,05$ menunjukan bahwa perlakuan yang digunakan berbeda signifikan terhadap perlakuan yang lain. Selain itu, dari hasil uji Duncan terlihat bahwa kontrol positif yang menggunakan abate yaitu 25,00, ekstrak bunga kecombrang $15 \%$ memiliki tingkat efektivitas yang paling tinggi yaitu 24,80, ekstrak bunga kecombrang $10 \%$ yaitu 24,60 , ekstrak bunga kecombrang 5\% yaitu 13,00 , dan yang paling rendah kontrol negatif dengan menggunakan aquades yaitu 0,00. Maka ekstrak 10\% dan ekstrak $15 \%$ memiliki kemampuan yang sama dalam membunuh larva, sehingga konsentrasi 
ekstrak ini dapat menggantikan abate sebagai larvasida.

Berdasarkan hasil dari skrining fitokimia ekstrak bunga kecombrang adalah dilihat pada tabel di atas (4.4). Bahwa aktivitas larvasida yang tertinggi dari tanaman bunga kecombrang terhadap larva nyamuk merupakan efek kombinasi dari berbagai kandungan fitokimia yaitu alkaloid : 4,62\%, terpenoid : $3,08 \%$, flavonoid : $2,11 \%$, saponin : $1,92 \%$, minyak atsiri $: 1,67 \%$ dan Tanin $0,31 \%$. Alkaloid dapat mendegradasi dinding sel dan merusak sel, dan juga mempengaruhi sistem saraf dengan cara menghambat kerja enzim asetilkolinesterase (Putri dkk., 2017). Menurut Putri dkk., (2018) bahwa senyawa terpenoid yang memiliki kemampuan bekerja sebagai racun kontak karena memiliki kemampuan untuk menembus bagian kutikula serangga dan juga bisa menjadi anti feedant yaitu menghambat proses makan larva. Flavonoid dapat masuk kedalam tubuh larva melalui sistem pernafasannya lalu menimbulkan kerusakan pada sistem pernafasan (Koraag dkk., 2016).

Menurut Putri dkk., (2017) bahwa senyawa saponin yang diduga mengandung hormon steroid yang dapat menurunkan tegangan pada permukaan selaput mukosa traktus digestivus larva sehingga dinding traktus digestivus menjadi rusak. Minyak atsiri memiliki efek insektisida sebagai repelen, atrakan, fumigant dan penghambat nafsu makan (Hartati., 2012). Tanin dapat menurunkan kemampuan mencerna makanan dengan cara menurunkan aktivitas enzim pencernaan serta mengganggu aktivitas protein usus (Juwita dkk., 2013).

Hasil data yang diperoleh dapat diartikan, bahwa larvasida ekstrak bunga kecombrang (Etlingera elatior Jack R.M sm) perlakuan $10 \%$ dan $15 \%$ mampu membunuh larva nyamuk Culex quinquefasciatus dalam waktu 12 jam dibandingkan dengan perlakuan 5\%. Ekstrak bunga kecombrang (Etlingera elatior Jack R.M sm) $10 \%$ dan $15 \%$ dengan abate memiliki hasil yang tidak berbeda nyata. Penggunaan ekstrak bunga kecombrang (Etlingera elatior Jack R.M sm) $10 \%$ dan $15 \%$ dapat menggantikan abate sebagai herbal larvasida pada larva nyamuk Culex qiunquefasciatus Say.

\section{KESIMPULAN}

Berdasarkan hasil penelitian dan pembahasan diperoleh kesimpulan bahwa ekstrak bunga kecombrang (Etlingera elatior Jack R.M sm) mempunyai daya larvasida terhadap larva nyamuk Culex quinquefasciatus Say.

\section{REFERENSI}

Ahdiyah, I., dan Purwani ,K.I. 2015. Pengaruh Ekstrak Daun Mangkokan (Nothopanax scutellarium) sebagai Larvasida Nyamuk Culex sp. Jurnal Sains dan Seni ITS. Surabaya. 4(2):2337-3520.

Fuadzy, H dan Marina, R. 2012. Potensi Daun Dewa (Gynura Pseudochina L. DC.) Sebagai Larvasida Aedes Aegypti (Linn). Aspirator. Ciamis. 4(1): 7-13.

Hartati, S.Y. 2012. Prospek Pengembangan Minyak Atsiri Sebagai Pestisida Nabati. Perspektif. Bogor. 11(1): 45-58

Juwita, E., Mahatma, R., dan Fitmawati. 2013. Mortalitas dan Pertumbuhan Larva Nyamuk Culex sp. Akibat Pemberian Ekstrak Kulit Jengkol (Archidendron pauciflorum Benth.). Fakultas Matematika dan Ilmu pengetahuan alam. Pekanbaru.

Koraag, M.E., Hayani, A., Rina I., dan Octaviani. 2016. Efikasi Ekstrak Daun dan Bunga Kecombrang (Etlingera elatior) terhadap Larva Aedes aegypti. Aspirator. Donggala. 8(2):63-68.

Khumaisah, L.L., Kadarohman, A., dan Eko, R. 2010. Efektivitas Biolarvasida Ekstrak Etanol Limbah Penyulingan Minyak Akar Wangi (Vetivera zizanoides) Terhadap Larva Nyamuk Aedes Aegypti, Culex Sp, Dan Anopheles Sundaicus. Jurnal Sains dan Teknologi Kimia. Bandung. 1(1):59-65.

Low, V.L., Chen, C.D., Lee, H.L., Lim, P.E., Leong, C.S., and Azirun, M.S. 2012. Nationwide Distribution of Culex Mosquitoes and Associated Habitat Characteristics at Residential Areas in Malaysia. Journal of the american mosquito control association. 28(3): 160-169. 
Pradani, F.Y., Ipa, M., Mariana, R., dan Yuliasih, Y. 2011. Status Resistensi Aedes aegypti dengan Metode Susceptibility di Kota Cimahi terhadap Cypermethrin. Aspirator. Ciamis. 3(1): 18-24.

Putri, D.M., Sarong, M.A., dan Supriatno. 2018. Efektivitas Larvasida Ekstrak Etanol Daun Alpukat Terhadap Mortalitas Larva Aedes Aegypti Dan Culex Quinquefasciatus. Jurnal Edubio Tropika. Universitas Syiah Kuala. 6(1):1-72.

Putri, R., Wargasetia, T.L., dan Tjahjani, S. 2017. Efek Larvasida Ekstrak Etanol Daun Pandan Wangi (Pandanus amaryllifolius Roxb.) Terhadap Larva Nyamuk Culex sp. Artikel Penelitian. Global Medical and Health Communication. Bandung. 5(2).

Wijayanti, M.P., Yuliawati, S dan Hestiningsih, R. 2015. Uji Toksisitas Ekstrak Daun Tembakau (Nicotiana tobacum L.) Dengan Metode Maserasi Terhadap Mortalitas Larva Culex quinquefasciatus Say. Di Laboratorium. Jurnal Kesehatan Masyarakat. 3(1): 148. 